\title{
Література:
}

1. Каразия Н. А. Лингвопрагматическое исследование конфликтного дискурса. Вестник КРАУНЦ. Сер.: Гуманитарные науки. 2006. № 2 (8). C. $72-88$.

2. Комалова Л. Р. Лингвистический аспект конфликтологической компетентности: автореф. дис. ... канд. филол. наук: 10.02.21. Москва, 2009. $25 \mathrm{c}$.

3. Третьякова В. С. Речевая конфликтология: проблемы, задачи, перспективы. Вестник Челябинского государственного университета. 2013. № 1 (292). C. 279-282.

4. Leech Geoffrey. Principles of Pragmatics. London, New York: Longman, 1983. $257 \mathrm{p}$.

DOI https://doi.org/10.30525/978-9934-26-180-0-26

\section{RECEPTION OF UKRAINIAN POETIC LITERARY DISCOURSE IN FRENCH-SPEAKING COUNTRIES (1961-2021)}

\author{
Chystiak D. O. \\ Doctor of Philological Sciences, Associate Professor, \\ Professor at the Department of Romanic Philology, \\ Scientific and Pedagogic Institute of Philology \\ Kyiv National Taras Shevchenko University \\ Kyiv, Ukraine
}

After the restoration of Ukraine's independence thirty years ago, literary exchanges with French-speaking countries reached a new level, although we should note some problems in the reception of works by Ukrainian authors, so the identification of achievements in this field seems relevant. The aim of this study is to characterize the current state, highlight problems and outline the perspectives for the spread of Ukrainian literary tradition in French-speaking countries._In contemporary philology, there are some valuable studies on the history of Franco-Ukrainian literary relations, which, however, relate to particular problems. The current period of the poetic literary process is either ignored or studied not as a systemic process $[2 ; 4 ; 5]$.

The $2^{\text {nd }}$ part of $\mathrm{XX}$ century is marked by the growing interest in the Ukrainian literary tradition in the French-speaking world. However, a number of publications prepared in Kyiv by the editorial board of foreign literature of 
the «Dnipro» publishing house (selected works by Taras Shevchenko, Ivan Franko, Lesia Ukrainka, Andriy Malyshko, Maxym Rylsky, Pavlo Tychyna, etc.) with the involvement of native or immigrant translators in French did not influenced the French-language book market. A gorgeous problem happened at «Dnipro» Publishing House in 2014: at the request of the State Committee for Television and Radio Broadcasting of Ukraine the so-called "new edition" of Shevchenko's «Kobzar» was published, in French translation by Victoria Kulikova for 1,000 copies. In fact, the mysterious pseudo-translator Ms. Kulikova did not translate anything for this publication, did not write afterwords and notes, because it is a clumsy reprint of the 1978 edition, this time without mentioning translators Henri Abril, Nina Nassakina, Alexander Karvovsky and Kazimir Szymanski as well as the commentator from the Academy of Sciences of the USSR Evhen Kyrylyuk.

Another edition of Taras Shevchenko's Selected Works translated by Eugene Guillevic in the series «Poets of Our Time» published by Pierre Seghers in Paris in 1961 under the auspices of the National Commission of the Ukrainian SSR at UNESCO, with a 45-page preface by Maxym Rylsky and Olexandr Deich, can be considered as a successful Soviet publishing project. Of course, Hryhoriy Kochur was right when he noted lexical redundancy as well as refusal to preserve the basic rhythmic and melodic features of Shevchenko's language, but Eugene Guillevic's poetic talent managed to convey discursive meaning at a high level. We should note that this edition had the greatest publicity and remains accessible to French-speaking readers in the largest French book collections and second-hand bookstores. The edition «Taras Shevchenko, 18141861. His life and work» edited by Arkady Zhukovsky and Kalena Uhryn (First Ukrainian Printing House of France, 1964; 2nd reprint edition by Du Dauphin Publishing House, 2004) provides a comprehensive reproduction of the Shevchenko's word from the versions of the first half of the XXth century (among them are some talented versions, «Cherry Orchard Around the House» by Fernand Mazade, «Days Pass» by Myroslava Maslov, «I Don’t Care» by Charles Tillac) but the vast majority of translations remain word-to-word versions. We should also mention the literary collection «New literary wave in Ukraine» edited by Myroslava Maslov (Paris, The First Ukrainian Printing House in France, 1967) including poems by Lina Kostenko, Ivan Drach, Mykola Vinhranovsky, Vitaly Korotych, Vasyl Symonenko, Hryhoriy Kyrychenko, Iryna Zhylenko, Liydmyla Skyrda, Vasyl Holoborodko, Evhen Gutsalo, etc.) and a brochure by Leonid Novichenko «Taras Shevchenko, a great Ukrainian poet» (Paris, UNESCO, 1982).

The fundamental 1202-page French-language work «Anthology of Ukrainian Literature from the XI to the XX century» should be mentioned as a 
great editorial project prepared by the Shevchenko Scientific Society in Europe and edited by Michel Cadot, Arkady Zhukovskyi, Viktor Koptilov, Emile Kruba and Irene Popovych, published in 2004 at Olena Teliha Publishing House in Kyiv. The publication is a compendium of most of the available (and often specially prepared) French reproductions of Ukrainian literature from "Words of Law and Grace" by Ilarion to the poetry of Yuri Andrukhovych, together with bio-bibliographic references about authors with a short socio-cultural description of their work, which provide an adequate cultural and historical panorama of the Ukrainian literary process, without ideological distortions of the Soviet period. At the same time, it should be noted that it is a pity that such a fundamental publication was not published by a French publishing house and was not properly presented in the French-language media, as it could be the basis for further scientific and artistic projects and reveal the Ukrainian literary tradition as an organic diachronic process of establishing the cultural semiotic sphere. At the same time, it should be noted that most of the presented translations have much more informative than aesthetic function, as they are performed not by professional writers but by amateurs of the Ukrainian literary word, mostly from Ukrainian emigration circles.

In recent years, work on the presentation of Ukrainian poetry in France and French-speaking countries has intensified. In 1996, Igor Kalynets' collection «The Coronation of the Scarecrow» (Beuvry: House of Poetry Nord-pas-deCalais, translated by Roman Babowal) was published. In 2010, the FrenchUkrainian edition of Oleksiy Dovhy's «Glass of Roses» (Paris: L'Harmattan, translated by Ivan Ryabchi and Dmytro Chystiak) was published, and in 2013 we prepared the French and Flemish version of this edition (Rozenkelken; Brussels: L'Esprit des Aigles, translated into Flemish by Lynn Wouters-Van der Talen)._In 2012 we prepared the selected poems by Anna Bagryana «Anchor» (Brussels: Esprit des Aigles, translated by Dmytro Chystiak), as well as the French-Ukrainian collection of Dmytro Chystiak «High Garden» (Rouen, Christophe Chomant Publishing House, translated by the author. Three editions of the Anthology of Ukrainian poetry «Solar Clarinets» (Paris: Solenzara Cultural Institute, 2013, 2014; Brussels: L'Esprit des Aigles, 2021, translated by Dmytro Chystiak) were published, which included works by 50 authors from Taras Shevchenko to young poets. Stanislav Bondarenko's book «A Night's Conversation with Europe, or the Secrets of Our Letters», 2014) was published by Solenzara Cultural Institute with a foreword by Mykola Zhulinsky.

In 2014, Taras Shevchenko's «Testament» selected collection was published in the same publishing house translated by Dmytro Chistyak, with forewords by Stanislav Dovhyi, Dmytro Chistyak, Yuri Mosenkis, Dmytro Gorbachev and Olena Solomarska) opened a series of publications of the European Academy 
of Sciences, Arts and Literature together with the Young Academy of Sciences of Ukraine under the patronage of Stanislav Dovhyi on the presentation of musical works by famous Ukrainian composers on the poems of Ukrainian poets with observance of the rhythmic melodies of the original. Later, Dmytro Chystiak prepared in this series by Solenzara Cultural Institute Publishing House the books «Gray Swallow» by Borys Oliynyk (2015), and later, in the Paris publishing house «Sigillaire» on the same principle he translated the works of Ivan Franko («It is a great time!» (2016) and Ivan Drach's «Volcanic Etude» (2017, music by Volodymyr Huba). On the occasion of the 200th anniversary of Taras Shevchenko, the collection of Taras Shevchenko's Kobzar was published by the Parisian publishing house «Bleu et jeune», edited by Tatiana Syrochuk. We should greet an extensive system of notes to explain Ukrainian cultural realities, the translation of which is mostly not given in the text. Therefore, the informative function comes to the fore, overshadowing the aesthetics, and complete non-compliance with the rhythmic and melodic structure of the original can hardly be considered motivated, which generally brings the reproduction closer to the line text.

In 2015, selected poems by Ihor Pavlyuk «Magma of Polissia» were published in French (Rouen: Christophe Chomant Publishing House, translated by Dmytro Chystiak and Athanase Vantchev, foreword by Dmytro Drozdovskyi). On the occasion of being elected full members of the European Academy of Sciences, Arts and Literature and honored with the EASAL Grand Prize in Poetry we both with Nicole Laurent-Catrice translated in the series «Poets of the Five Continents» in the publishing house «L'Harmattan» the books «The Red Frog of the Heart» by Olexandr Korotko (2017) and «Silver Blood» by Pavlo Movchan (2018).

The material analyzed by us attests the discreteness of the presentation of Ukrainian poetic heritage in French-speaking countries. It is time to prepare an updated «Anthology of Ukrainian Literature from the XI to the XXI century» and a series of panoramic anthological collections of poetry, drama, essays according to the diachronic or thematic principle. Such a work should definitely involve French-speaking literary critics and translators in collaboration with Ukrainian scientific, cultural state and public institutions. We suggest also a thorough analysis of the socio-cultural reception of inventoried translations in French-Speaking media, state and public cultural institutions to delimitate their role in the francophone literary process with the development of appropriate recommendations. 


\section{References:}

1. Anthologie de la littérature ukrainienne du XIe au XXe siècle. Kyiv: Editions Olena Teliha, 2004. 1204 p.

2. Chevtchenko J. Ukraine. Bibliographie des ouvrages en français XVIIe-XXe siècles. Paris: Publication de l'Est Européen, 2000. 222 p.

3. Chevtchenko T. Testament. Poèmes mis en musique. Préfaces de Stanislav Dovgiy, Iourii Mosenkis, Dmytro Tchystiak, Olena Solomarska et Dmytro Horbatchev. Traduit du français et édité par Dmytro Tchystiak. Paris: Institut culturel de Solenzara, 2014. 68 p.

4. Chystiak D. Ukrainian literature in French-Speaking countries in the diachronic aspect: problems and perspectives. Vcheni Zapysky TNU imeni V. I. Vernadskoho. 2021. Vol. 32. Issue 5. Part 1. Pp. 214-222.

5. Piaseckyj O. Bibiography of Ukrainian Literature in English and French: Translations and Critical Works (1950-1986). Ottawa - London - Paris: University of Ottawa Press, 1989. 386 p. 